\title{
Formalin-fixed paraffin-embedded tissue: The holy grail of clinical proteomics
}

\author{
Valérie Broeckx ${ }^{1 *}$, Lise Peeters $^{1 *}$, Evelyne Maes $^{2}$, Lentel Pringels $^{1}$, Eddy-Tim Verjans $^{1}$ \\ and Bart Landuyt ${ }^{1}$ \\ ${ }^{1}$ Functional Genomics and Proteomics Unit, KU Leuven, Leuven, Belgium \\ ${ }^{2}$ VITO, Mol, Belgium
}

Tissue is the most relevant biological material to gather insight in disease mechanisms by means of omics technologies. However, fresh frozen tissue, which is generally regarded as the best imaginable source for such studies, is often not available. In case it is available, the different ways of storage (e.g. $-20^{\circ} \mathrm{C},-80^{\circ} \mathrm{C}$, liquid nitrogen, etc.) hamper the conduction of reproducible multicenter studies because of different protein degradation rates. Formalin-fixed paraffin-embedded (FFPE) tissue on the contrary is considered as a valuable alternative for fresh frozen tissue, because only a few standard operation procedures are applied worldwide for the preparation of these tissues and because they are all stored in the same way. However, a study on the impact of the different preparation protocols for FFPE tissue was still lacking. Therefore, Bronsert et al. in this issue [Bronsert, P., Weißer, J., Biniossek, M. L., Kuehs, M. et al., Proteomics Clin. Appl. 2014] conducted such a study that provides proof that there is no significant effect between these sample preparations procedures, and thereby they further open the gate for FFPE tissues to enter the field of clinical proteomics.

\section{Keywords:}

Biomarkers / Cancer / Tissue proteomics

High-quality collections of biological samples are essential to gain both fundamental insights in disease mechanisms as well as in more applied research leading to the identification of potential biomarkers. Although frozen biobanked material is very popular, the limited availability of these tissues restricts their use in clinical research. FFPE tissue offers a good alternative to frozen material, but has been left aside by proteomics researchers for decades, because of the inherent difficulties associated with the extraction of the proteins and artificial modifications that are induced by the fixation process. However, FFPE tissues form an interesting source of clinical samples for several reasons: (i) there is a general long patient follow-up history, (ii) FFPE tissues are routinely prepared for pathological analysis worldwide, (iii) these tissue collections offer the best chances to obtain large cohorts

Correspondence: Dr. Bart Landuyt, Functional Genomics and Proteomics, KU Leuven, Naamsestraat 59, BE-3000 Leuven, Belgium E-mail: bart.landuyt@kuleuven.be

Abbreviation: FFPE, formalin-fixed paraffin-embedded of samples over a short period of time. For all these reasons, many attempts have been made recently to extract proteins from FFPE tissues for proteomics analysis.

Efforts leading toward better practices for the extraction, separation, MS analysis, and bioinformatics interpretation of FFPE tissue based proteomics are still highly demanded. Although the number of publications related to the proteomic analysis of FFPE tissues have significantly increased during the past years (Fig. 1), additional technological improvements for the exploitation of this rich source of tissues for clinical proteomics purposes are still required. Therefore, efforts such as described in the article by Bronsert and co-workers in this issue of Proteomics Clinical Applications [1] are highly appreciated and form the basis for future proteomics research on FFPE tissues. The knowledge that the different routinely employed procedures for the preparation of FFPE tissues do not influence downstream proteomics analysis is an important insight that will further enhance research in this field.

\footnotetext{
*These authors have contributed equally to this work.
} 


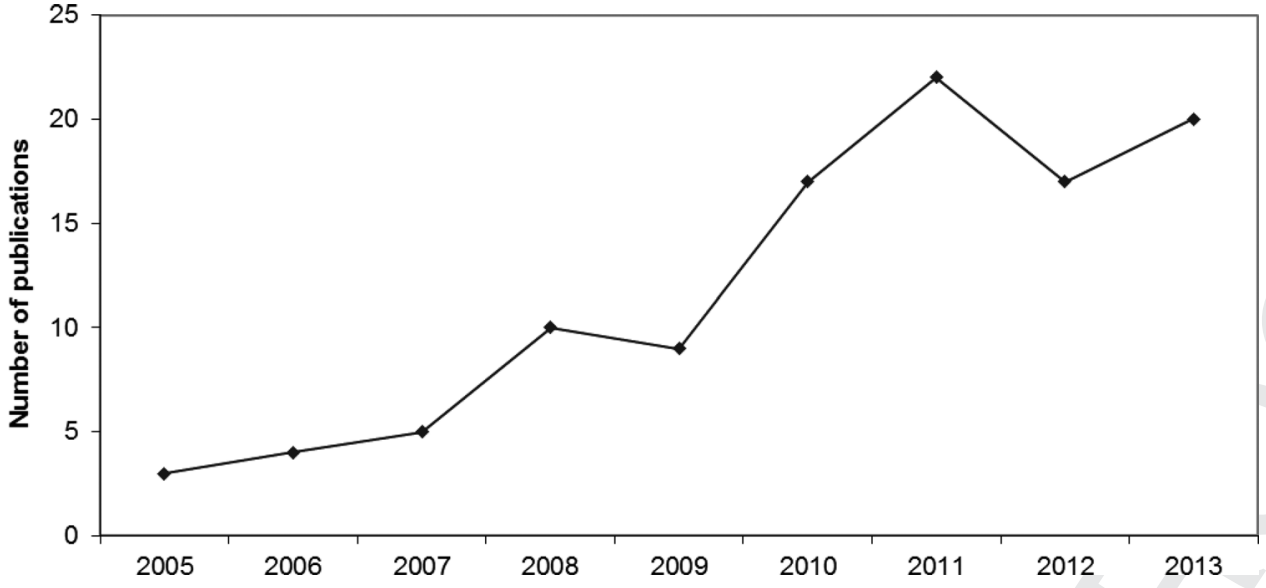

Figure 1. Number of publications regarding proteomics studies on FFPE tissues (source: PubMed).
Additional insights regarding the extraction, separation, analysis, and bioinformatics interpretation of FFPE-based proteomics are however still required to enable the full exploitation of these tissues before they might be considered as the holy grail of clinical proteomics.

\section{Reference}

[1] Bronsert, P., Weißer, J., Biniossek, M. L., Kuehs, M. et al., Proteomics Clin. Appl. 2014. 


\section{Author Query Form}

\begin{tabular}{ll}
\hline Journal & PRCA \\
Article & prca201400132 \\
\hline
\end{tabular}

Dear Author

During the copy-editing of your paper, the following queries arose. Please respond to these by marking up your proofs with the necessary changes/additions. Please write your answers clearly on the query sheet if there is insufficient space on the page proofs. If returning the proof by fax do not write too close to the paper's edge. Please remember that illegible mark-ups may delay publication.

\begin{tabular}{|c|c|c|}
\hline Query No. & Description & Remarks \\
\hline Q1 & Author: Please check the article title as typeset for correctness. & \\
\hline Q2 & $\begin{array}{l}\text { Author: Please provide department name for the second affiliation, if applicable. Also check both } \\
\text { the affiliations as typeset for correctness. }\end{array}$ & \\
\hline Q3 & Wiley: Please check reference citation "Bronsert et al." in abstract as typeset for correctness. & \\
\hline Q4 & Author: Please check the abbreviation list as typeset for correctness. & \\
\hline Q5 & Author: Please check the footnote "'These authors have contributed.... As typeset for correctness. & \\
\hline Q6 & $\begin{array}{l}\text { Author: Please check the author name "Bronsert, } \mathrm{P} \text { " and also provide article title, volume number, } \\
\text { and page range for Ref. } 1 .\end{array}$ & \\
\hline
\end{tabular}


Required software to e-Annotate PDFs: Adobe Acrobat Professional or Adobe Reader (version 8.0 or above). (Note that this document uses screenshots from Adobe Reader $\mathbf{X}$ )

The latest version of Acrobat Reader can be downloaded for free at: http://get.adobe.com/reader/

Once you have Acrobat Reader open on your computer, click on the Comment tab at the right of the toolbar:

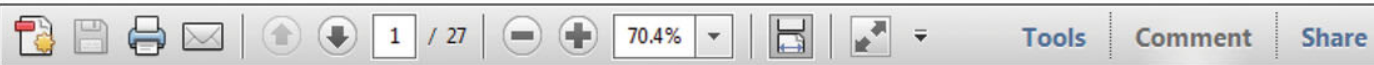

This will open up a panel down the right side of the document. The majority of tools you will use for annotating your proof will be in the Annotations section, pictured opposite. We've picked out some of these tools below:

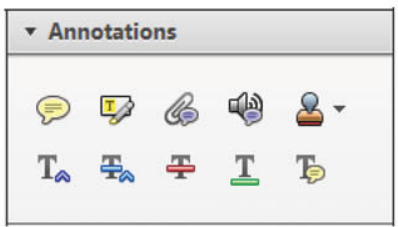

\section{Replace (Ins) Tool - for replacing text.}

Strikes a line through text and opens up a text box where replacement text can be entered.

\section{How to use it}

- Highlight a word or sentence.

- Click on the Replace (Ins) icon in the Annotations section.

- Type the replacement text into the blue box that appears.

Idard tramework for the analysis of $\mathrm{m}$ icy. Nevertheless, it alse-led to exog،

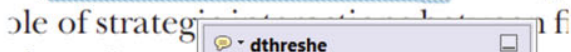
aber of comp 08/06/2011 15:58:17 $\quad$ O is that the $\mathrm{s} 1$, which led of nain compo: be level, are exc nc

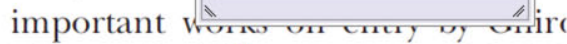
M henceforth) 1 we snen the 'hlarl b

3. Add note to text Tool - for highlighting a section to be changed to bold or italic.

T) Highlights text in yellow and opens up a text box where comments can be entered.

\section{How to use it}

- Highlight the relevant section of text.

- Click on the Add note to text icon in the Annotations section.

- Type instruction on what should be changed regarding the text into the yellow box that annears.

namic responses of mark ups ent with the VAR evidence

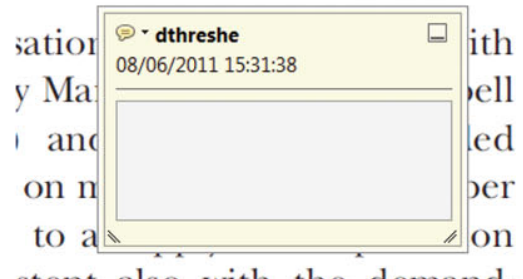

2. Strikethrough (Del) Tool - for deleting text.

空

Strikes a red line through text that is to be deleted.

How to use it

- Highlight a word or sentence.

- Click on the Strikethrough (Del) icon in the Annotations section.

there is no room for extra prohts al s ups are zero and the number of cet) values are not determined by Blanchard and Kiyetaki (1987), sfect competition in general equilil ts of aggregate demand and supply lassical framework assuming monol ean an evorennue number of firme

4. Add sticky note Tool - for making notes at specific points in the text.

Marks a point in the proof where a comment needs to be highlighted.

\section{How to use it}

- Click on the Add sticky note icon in the Annotations section.

- Click at the point in the proof where the comment should be inserted.

- Type the comment into the yellow box that appears.

lailu dilu suppiy silucks. Iviusl U1

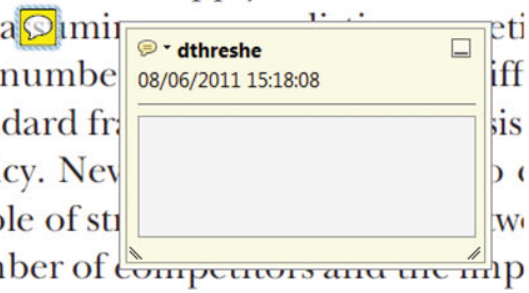
is that the structure of the secte 
5. Attach File Tool - for inserting large amounts of text or replacement figures.

Inserts an icon linking to the attached file in the appropriate pace in the text.

\section{How to use it}

- Click on the Attach File icon in the Annotations section.

- Click on the proof to where you'd like the attached file to be linked.

- Select the file to be attached from your computer or network.

- Select the colour and type of icon that will appear in the proof. Click OK.

E N D

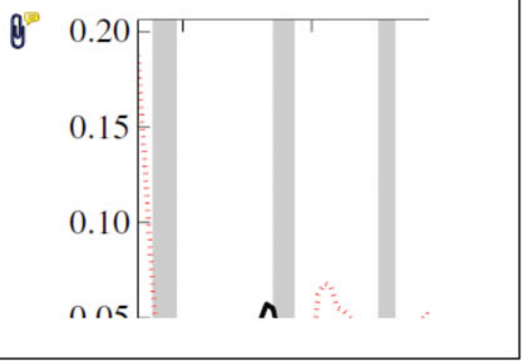

6. Add stamp Tool - for approving a proof if no corrections are required.

B. Inserts a selected stamp onto an appropriate place in the proof.

How to use it

- Click on the Add stamp icon in the Annotations section.

- Select the stamp you want to use. (The Approved stamp is usually available directly in the menu that appears).

- Click on the proof where you'd like the stamp to appear. (Where a proof is to be approved as it is, this would normally be on the first page).

of the Dusiness cycie, starting with the on perfect competition, constant ret ef otaki (1987), has introduced produc general equilibrium models with nomin

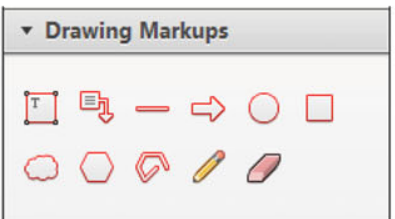

How to use it

Click on one of the shapes in the Drawing Markups section.

- Click on the proof at the relevant point and draw the selected shape with the cursor.

- To add a comment to the drawn shape, move the cursor over the shape until an arrowhead appears.

- Double click on the shape and type any text in the red box that appears.
7. Drawing Markups Tools - for drawing shapes, lines and freeform annotations on proofs and commenting on these marks.

Allows shapes, lines and freeform annotations to be drawn on proofs and for comment to be made on these marks.

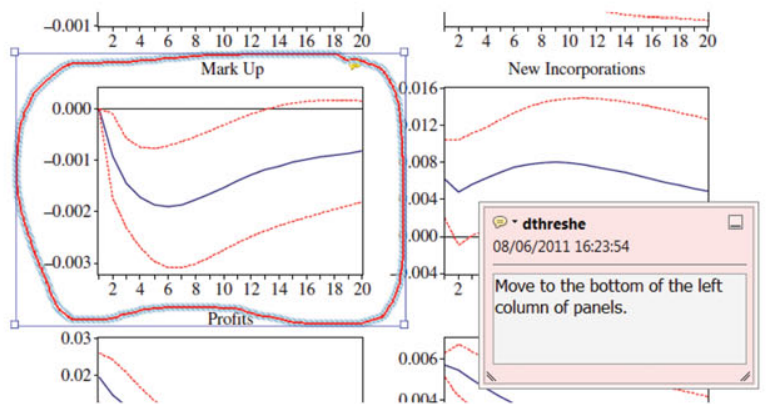

For further information on how to annotate proofs, click on the Help menu to reveal a list of further options:

\begin{tabular}{|l|l|l|l|l|}
\hline 2- ecoj_2384_CrxRev2_EV_19-Jul-10.pdf - Adobe Reader \\
\hline File Edit View Window
\end{tabular}




\section{Proteomics \\ Clinical Applications}

Please correct your galley proofs and return them within $48 \mathrm{~h}$ of receipt.

Note: The editors reserve the right to publish your article without your corrections if the proofs do not arrive in time.

Important

Please note that, due to the size constraints of emailed attachments, the attached proofs are low resolution; however, please be assured that high resolution versions will be used for printing.

Check the enclosed galley proofs very carefully, paying particular attention to the formulae, figures, numerical values, and tabulated data. An author query (AQ) in the border indicates unclear or missing information that requires your attention. For the complete query, please consult the attached list. Note that the author is liable for damages arising from incorrect statements, including misprints.
Your corrections should be provided as a list (e.g. in Word format), including the page number, column, section number and line at which the correction occurs. In addition, we ask that you provide a scanned pdf of the proof with corrections, if possible, to reduce the risk of errors.

Please return your corrections by email to the following address:

E-Mail: wiley.weinheim@aptaracorp.com

Please limit corrections to printing errors; costs incurred for any further changes or additions will be charged to the author, unless such changes have been accepted by the editor.

Reprints may be ordered by filling out the accompanying form and should be returned to the Editorial Office. 


\section{PROTEOMICS}

Please complete this form and return it via E-Mail or Fax:

Reprint Order Form

E-mail: proteomics@wiley.com

Fax: +49 (0) 6201606525

Wiley-VCH Verlag GmbH \& Co. KGaA

Proteomics Clinical Applications

Boschstr. 12

69469 Weinheim

Germany
Manuscript No.: 201400132

Costumer No.: (if available)

Purchase Order No.:

Author:

Date:

\section{Reprints}

Reprints are available at the rates given below only if ordered now. Please note that prices will be substantially higher after publication of the issue. All given prices are including postage and handling charges and excluding tax (VAT). If more than 500 copies are ordered, special prices are available upon request.

Please send me and bill me for

no. of reprints via

$\square$ airmail (+ 25 Euro)
$\square$ surface mail
$\square$ Fedex No.:

no. of copies of this issue

(1 copy: 20 Euro)

$$
\begin{gathered}
\text { via } \square \text { airmail (+ } 25 \text { Euro) } \\
\square \text { surface mail } \\
\square \text { Fedex No.: }
\end{gathered}
$$

high-resolution PDF file (330 Euro).

My e-mail address:

\section{$\rightarrow$ Special Offer}

If you order 200 or more reprints you will get a PDF file for half price. reprints and a PDF file.

Please note: It is not permitted to present the PDF file on the internet or on company homepages

\section{My VAT number is:}

\section{Information regarding VAT}

Please note that from German sales tax point of view, the charge for Reprints, Issues or Posters is considered as "supply of goods" and therefore, in general, such delivery is a subject to German sales tax. However, this regulation has no impact on customers located outside of the European Union. Deliveries to customers outside the Community are automatically tax-exempt. Deliveries within the Community to institutional customers outside of Germany are exempted from the German tax (VAT) only if the customer provides the supplier with his/her VAT number. The VAT number (value added tax identification number) is a tax registration number used in the countries of the European Union to identify corporate entities doing business there. It starts with a country code (e.g. FR for France, GB for Great Britain) and follows by numbers.
Mail reprints / copies of the issue to:

Send bill to:

\section{Date, Signature}

\section{Credit Card Payment}

VISA, MasterCard, AMERICAN EXPRESS

Please use the Credit Card Token Generator located at the website below to create a token for secure payment. The token will be used instead of your credit card number.

\section{Credit Card Token Generator:}

https://www.wiley-vch.de/editorial_production/index.php

Please transfer your token number to the space below.

\section{Credit Card Token Number}

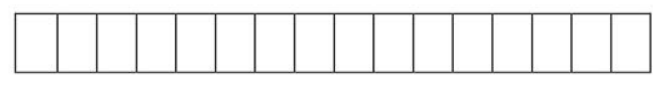

Wiley-VCH Verlag GmbH \& Co. KGaA; Location of the Company: Weinheim; Chairman of the Supervisory Board: Stephen Michael Smith,

Trade Register: Mannheim, HRB 432833, General Partner: John Wiley \& Sons GmbH,

Location: Weinheim, Trade Register Mannheim, HRB 432296,

WI LEY-VCH

Managing Directors: Bijan Ghawami, Dr. Jon Walmsley 
Die unten genannten Preise gelten nur für Sonderdrucke, die im Lauf des Jahres 2014 und vor dem Druck des Heftes bestellt werden. Mindestbestellmenge: 50 Exemplare. Lieferung: ca. 3 Wochen nach Erscheinen des Werkes, aus dem der Sonderdruck stammt.

Die Anfertigung von Sonderdrucken nach dem Druck einer Zeitschrift ist wesentlich teurer, da sie im Verlag und in der Druckerei zusätzliche Arbeitsgänge erfordert. Bitte bestellen Sie Ihre Sonderdrucke daher rechtzeitig und in ausreichender Stückzahl.

Bei Abnahme von mehr als 500 Exemplaren gelten Sonderpreise, die wir auf Anfrage mitteilen werden.

Ganze Hefte können von Autoren zu einem ermäßigten Preis bestellt werden.

Verpackung und Versandkosten (außer Luftpost) sind in den unten genannten Preisen enthalten. Die Mehrwertsteuer wird extra berechnet.

Sonderdrucke/Hefte werden per Schiff nach Übersee verschickt. Sollten Sie an einer schnelleren Beförderung per Luftpost interessiert sein, vermerken Sie dies auf beiliegendem Bestellformular. Bitte beachten Sie aber, dass Ihnen für diesen Versandweg die Kosten in Rechnung gestellt werden.

\section{Price List for Reprints (2014)}

The prices listed below are valid only for orders received in the course of 2014 and before the proofs pass for press. Minimum order is 50 copies. Delivery time will be approximately 3 weeks after the date of publication.

The production of reprints after a journal has been published is considerably more expensive since it requires extra operations on the publisher's and printer's side. Therefore, authors are requested to order reprints early and in sufficient numbers.

If more than 500 copies are ordered, special prices are available upon request.

Single issues are available to authors at a reduced price.

The prices include mailing and handling charges (with the exception of the additional costs incurred for air mail delivery). All Wiley-VCH prices are exclusive of VAT.

Reprints and issues are shipped by surface. If you are interested in receiving them by airmail mail please indicate this on the accompanying order form; however, please be aware that the costs incurred are considerably higher (surcharge Euro 25.00).

\begin{tabular}{|c|c|c|c|c|c|c|}
\hline \multirow{3}{*}{$\begin{array}{l}\text { Sonderdrucke/Reprints } \\
\text { Umfang (Seiten) } \\
\text { Size (pages) }\end{array}$} & \multicolumn{6}{|c|}{ Preis bei Abnahme von/Price for orders of (in Euro) } \\
\hline & 50 & 100 & 150 & 200 & 300 & 500 \\
\hline & Expl./copies & Expl./copies & Expl./copies & Expl./copies & Expl./copies & Expl./copies \\
\hline $1-4$ & $345,-$ & $395,-$ & $425,-$ & $445,-$ & $548,-$ & $752,-$ \\
\hline $5-8$ & $490,-$ & $573,-$ & $608,-$ & $636,-$ & $784,-$ & $1077,-$ \\
\hline $9-12$ & $640,-$ & $739,-$ & $786,-$ & $824,-$ & $1016,-$ & $1396,-$ \\
\hline $13-16$ & $780,-$ & $900,-$ & $958,-$ & $1004,-$ & $1237,-$ & $1701,-$ \\
\hline $17-20$ & $930,-$ & $1070,-$ & $1138,-$ & $1196,-$ & $1489,-$ & $2022,-$ \\
\hline $\begin{array}{l}\text { je weitere } 4 \text { Seiten/ } \\
\text { for every additional } \\
4 \text { pages }\end{array}$ & $147,-$ & $169,-$ & $175,-$ & $188,-$ & $231,-$ & $315,-$ \\
\hline Hefte/lssues & 1 Exemplar/ & py: 25,- Eur & PDF ( & resolution) & -Euro & \\
\hline
\end{tabular}

Postage and handling charges included. All Wiley-VCH prices are exclusive of VAT.

Prices are subject to change. 